


\section{Um pouco da história da Geografia do Colégio de Aplicação da UFRGS: uma entrevista com a professora Neiva Otero Schäffer}

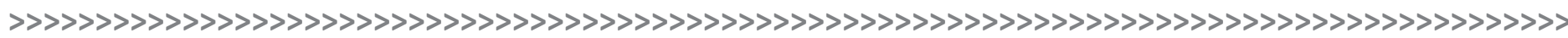

Victor Hugo Nedel Oliveira* Neiva Otero Schäffer ${ }^{* *}$

\begin{abstract}
Resumo:
A professora Neiva Otero Schäffer foi professora de Geografia no Colégio de Aplicação da UFRGS entre os anos de 1966 e 1969. Vivenciou importantes momentos históricos em seu espaço e tempo de trabalho. Este artigo apresenta uma retomada de sua trajetória, dando destaque para suas experiências de vida, acadêmicas e profissionais, bem como assinalando práticas de ensino de Geografia as quais a professora Neiva reconhece como de destaque. São apresentadas sínteses analíticas da vida e obra desta professora que colaborou na construção de um ensino de Geografia diferenciado. Para finalizar a professora Neiva apresenta, a partir de suas experiências, algumas pistas para os jovens professores de Geografia.
\end{abstract}

\section{Palavras-chave:}

Escola. Geografia. Educação.

\section{Resumen:}

La profesora Neiva Otero Schäffer fue profesora de geografía en el Colégio de Aplicação da UFRGS desde 1966 hasta 1969. Experimentó importantes momentos históricos en su espacio y tiempo de trabajo. Este artículo presenta una retomada de su carrera, destacando sus experiencias de vida, académicas y profesionales, así como señalando prácticas de enseñanza de geografía que la profesora Neiva reconoce como sobresalientes. Se presentan resúmenes analíticos de la vida y el trabajo de esta maestra que colaboró en la construcción de una enseñanza de geografía diferenciada. Para concluir el artículo, la professora Neiva presenta, a partir de sus experiencias, algunas pistas para los jóvenes profesores de geografía.

\section{Palabras-clave:}

Escuela. Geografia. Educación.

Ser professor no mundo contemporâneo e o regate da vida e das práticas dos professores vêm se intensificando na produção acadêmica recentemente, tornando-se uma importante temática da análise sobre os profissionais da educação. As inquietações acadêmicas com a formação de professores e com a profissão docente ganham sentido também a partir desses regates históricos e de suas análises.

Buscando colaborar no encontro de respostas para as questões educacionais da contemporaneidade, pesquisadores do campo da educação vêm investindo em estudos voltados para memórias e trajetórias docentes. Autores como Castro (2005), Fontana (2000), Freitas (2000) e Vidigal (1996) já desenvolveram estudos a respeito do resgate da
* > Doutor em Educação, professor do Departamento de Humanidades do Colégio de Aplicação da Universidade Federal do Rio Grande do Sul (UFRGS). E-mail: victor.juventudes@gmail.com.

** > Mestra em Planejamento Urbano e Regional, professora aposentada do Departamento de Geografia da Universidade Federal do Rio Grande do Sul (UFRGS). E-mail: neivasch@terra.com.br. 
memória de professores e encontraram importantes achados de pesquisa que colaboraram na reflexão de suas práticas docentes no contemporâneo.

Uma forma importante de resgatar o passado é ouvir antigas professoras e antigos professores que exerceram a docência em outros tempos, tempos estes nos quais os problemas na educação eram outros e as realidades social, econômica e política do país eram diferentes.

Desta forma, buscando contribuir com as discussões em torno da profissão docente e da formação de professores na escola básica, ingressamos no túnel do tempo para resgatar, junto aos professores de Geografia aposentados do Colégio de Aplicação da UFRGS, aspectos da sua profissionalidade docente que acabam construindo distintas práticas de ensino de Geografia, as quais merecem memória, destaque e aprendizado.

Este artigo é um dos produtos do projeto de pesquisa Memória geográfica do Colégio de Aplicação da UFRGS: resgate das narrativas de professores de Geografia do $C A p / U F R G S$, que busca justamente resgatar as memórias do ensino de Geografia no Colégio de Aplicação da UFRGS, a partir das narrativas de professores de Geografia da instituição, já aposentados.

Neiva Otero Schäffer é licenciada (1968) em Geografia pela Universidade Federal do Rio Grande do Sul (UFRGS), tendo concluído o mestrado no Programa de Pós-Graduação em Planejamento Urbano e Regional (UFRGS) em 1993. Foi professora do Colégio de Aplicação da UFRGS entre os anos de 1966 e 1969. Além do Colégio de Aplicação da UFRGS, Neiva atuou, como professora de Geografia, na escola pública do Estado do Rio Grande do Sul, em cursos pré-vestibular, na rede privada de ensino de Porto Alegre e no Departamento de Geografia da UFRGS. Os principais interesses de pesquisa da professora Neiva giram em torno das questões ambientais, de população, estudos regionais, estudos fronteiriços e do ensino de Geografia.

A professora Neiva Otero Schäffer vivenciou respeitáveis momentos históricos em seu espaço e tempo de trabalho. Este artigo apresenta uma retomada de sua carreira, dando destaque para suas experiências de vida, acadêmicas e profissionais, bem como assinalando práticas de ensino de Geografia as quais a professora Neiva reconhece como de destaque. São apresentadas sínteses analíticas da vida e obra desta professora que colaborou na construção de um ensino de Geografia diferenciado. Para finalizar a professora Neiva apresenta, a partir de suas experiências, algumas pistas para os jovens professores de Geografia.

Entrevistador: Conte-nos um pouco sobre sua trajetória de vida pessoal, acadêmica e profissional, antes de chegar ao Colégio de Aplicação da UFRGS.

Neiva Otero Schäffer: Eu cheguei muito cedo ao Colégio de Aplicação da UFRGS, porque eu entrei ali em mil novecentos e cinquenta e oito. Era o quarto ano de vida do Colégio de Aplicação, um colégio, então, pouco conhecido. Houve impacto na família quando a Secretaria de Educação, que avaliava os alunos das quintas séries das escolas públicas, sugeriu que eu fizesse a prova naquela escola, que ninguém conhecia. Mas foi uma experiência muito boa, se ingressava através de uma seleção. O número de candidatos foi muito grande, seiscentos e poucos para trinta vagas. Fiz todo o período de ginásio e colegial no Aplicação. No colegial, havia uma experiência muito interessante de avaliação semestral e de currículo construído pelo aluno, tanto que cheguei no terceiro colegial e não fiz a disciplina de língua portuguesa e literatura, o que hoje seria inadmissível. Como eu havia optado pelo curso de geografia, e não havia geografia no terceiro ano, em consequência eu fiz a disciplina de geografia com a turma do segundo ano e abri 
mão da língua portuguesa porque os horários coincidiam. Foi um "evento" no colégio o fato de eu não precisar fazer a disciplina de literatura com o Appel que era maravilhosa, mas eles me deram um belo programa de estudos que eu venci com muito esforço, sozinha. Foi uma experiência nova e produtiva. Então, depois desse período que foi de formação de nível básico, fundamental e médio hoje, eu ingressei no Aplicação para lecionar geografia em maio de sessenta e seis, ou seja, no meu segundo ano de curso de geografia. Havia completado apenas um ano e três meses da gradução, o que foi possível graças à situação que o país vivia, na qual um candidato, por diferentes razões, podia ser indicado a uma vaga ou ele era chamado a ocupar a vaga e não havia discussão sobre os limites dessa decisão. Como eu entrei no curso de geografia, e apenas dois alunos haviam sido aprovados naquele vestibular de 1965, eu e outro colega, a universidade me chamou. Já me conheciam, já era do Aplicação, os professores conheciam, eu havia ingressado em primeiro lugar no Curso de Geografia. Foi tranquilo, ninguém discutiu a escolha, e nem tinham o que discutir, não se discutia mesmo. Então, minha entrada no Colégio de Aplicação como professora, foi em maio de 1966. A permanência foi até novembro de 1969, quando casei e fui morar no interior. Quando retornei, em 1972, retornei para a universidade onde eu já estivera também atuando. Fui convidada a atuar no antigo Curso Básico. Só em 1982, ingressei no curso de geografia. Para este cargo houve uma seleção, na época exigida pelos alunos do curso que não aceitavam mais a indicação do professor. Mas foi uma seleção de caráter interno, não foi um concurso público porque ainda não havia concursos. Eu não lembro quando começaram os concursos.

Entrevistador: Quais são as suas melhores memórias de seu tempo de trabalho no Colégio de Aplicação da UFRGS?

Neiva Otero Schäffer: Como aluna, o que eu sinto, retornando no tempo para responder a essa pergunta sobre a qual eu nunca pensei, eu acho que o Aplicação na época, no meu caso e de outro colega, era uma experiência pesada. Eu sempre gostei de estudar. No Aplicação nós tínhamos aulas de manhã e de tarde, das oito ao meio dia, depois das duas às cinco, menos quartas-feiras, que era o dia que nós dizíamos que era o dia dos professores namorarem. Na verdade era o dia das reuniões semanais dos professores e não havia aulas à tarde, mas havia nos sábados das oito ao meio dia. Então, era uma carga horária que não se imagina hoje. Mas o pesado não era a carga horária. Como o ingresso era por uma seleção bem puxada de provas escritas e orais, com alunos com onze anos de idade, o que se observava naquele período é que esses alunos vinham de uma classe econômica e cultural muito alta. Esse formato de ingresso sempre irá privilegiar aqueles que vêm de famílias mais aquinhoadas. Para mim, significava observar nos colegas algumas situações que nem imaginava. Por exemplo, vários colegas conseguiam passar as férias de inverno no Rio de Janeiro. Algo alheio ao meu ambiente familiar. Boa parte deles tinham sítios próximos a Porto Alegre e casa na praia, o que na minha experiência, proveniente de classe média, com um pai que tinha que suprir as necessidades de seis filhos, era inimaginável. A gente desfrutava de praia, mas num período curto. E também nas roupas, nas aquisições que vinham do exterior, nas coleções de etiquetas que naquela época eram usadas muito nas aulas de línguas. Descobri que as pessoas tinham acesso a um mundo absurdamente diferente. Então era uma desigualdade muito marcante, que a gente aos poucos foi assimilando e vai vencendo e vai criando amizades adolescentes, que se mantêm hoje, o que é impressionante. Mas à época, um pouco mais do que criança e adolescente, era 
bastante difícil compatibilizar os estudos com a identificação de uma desigualdade social que eu não conhecera na escola primária.

Já como professora, fiquei muito à vontade no Aplicação, porque daí a situação era outra. Eu havia saído do Aplicação há um ano e meio, quando eu ingressei como professora. Os professores que ficavam, digamos, tutelando os novos professores eram todos meus conhecidos, tinham sido meus professores, bons professores, excelentes professores. Eu me sentia em casa, eu me sentia à vontade, eu me sentia inclusive à vontade para fazer críticas sobre o processo de ensino ou para cumprimentá-los. Eles me acolheram muito bem. Então eu acho que me senti muito melhor como professora do Aplicação do que como aluna no Aplicação, mais confortável, mais em casa e mais à vontade. Na época o Aplicação estava no prédio da FACED, no centro, então era o lugar que eu convivia permanentemente ou como ex-aluna ou como aluna na universidade. No Aplicação eu estava em casa. O Aplicação foi sempre uma escola inovadora, foi muito inovadora, e eu lembro que os professores diziam que era uma escola de aplicação de novas metodologias e que, portanto, tinha que ser inovadora. Era de se imaginar o que havia nas outras escolas, que eram o livro de didática, a cópia, o ditado e a memorização. O Aplicação oferecia experiências excepcionais mesmo para quem não era criativo, mesmo para um professor, para um indivíduo que desejasse a docência sem ser criativo, mas que tivesse boa vontade. O Aplicação ensinava possibilidades de ser criativo. Por exemplo, as provas de educação artísticas eram eventos. Todos os alunos fazendo o exame final juntos, todas as sete turmas que existiam fazendo a mesma prova. Havia a possibilidade do aluno se preparar para um exame oral em Ciências com um tema escolhido no início do ano e que deveria ser defendido ao final do ano, inclusive apresentando alguma experiência prática, o que era algo também bastante inovador. No ensino médio, colegial à época, o fato de não existir a prova regular em todas as disciplinas também diferenciava o colégio. Alguns professores faziam prova, outros não faziam prova, o que também implicava autonomia de trabalho e comprometimento. Poucos alunos fugiam de cumprir isso, porque o "boletim" só chegava ao final de junho. Então, a conversa, o olho no olho com o professor e os trabalhos com os bilhetes dos professores, eram respeitados, porque se chegasse em junho e estivesse mal nos estudos não teria saída. Havia sempre um trabalho muito inovador no Aplicação naquela época. Acredito que hoje também haja muito a relatar e os professores têm relatado, pelo que acompanhei pelos Cadernos do Aplicação. Inclusive tenho alguma coisa publicada nos Cadernos. Também a filha, que foi aluna do Aplicação, mas em outro momento. Ela entrou já na época dos sorteios.

Entrevistador: Quais foram os seus principais desafios em seu tempo de trabalho no Colégio de Aplicação da UFRGS?

Neiva Otero Schäffer: Ser criativa! Oportunizar a alunos que ingressavam por seleção, que, portanto, eram muito bons, a possibilidade de ter vivido o que eu vivi, ou seja, não passar pela sala de aula apenas com livro didático, mas oferecendo possibilidades de aprender com autonomia. Trabalhar com leitura de mapas foi sempre um foco, porque acredito que isso é muito valioso. Sobre isto, lembro-me de duas experiências, uma no Aplicação e outra em uma escola estadual noturna, em Gramado. A dinâmica de trabalho foi a mesma, mas no Aplicação os alunos tiveram muito mais agilidade do que em Gramado, com alunos mais velhos, fora da série esperada, que trabalhavam todo o dia e que vinham às aulas, naquele frio, com chinelo de dedo, para um prédio em fase de acabamento e sem vidros. O que 
eu propus, levando histogramas de cinco diferentes espaços climáticos do Brasil, de obras do IBGE, foi que escrevessem, em dupla, três parágrafos. Um deveria localizar a cidade cujos dados estavam no histograma. Para isto, usaram o Atlas escolar. O segundo deveria tratar do volume e variação anual de pluviometria, e o terceiro deveria relatar a variação anual de temperatura e a amplitude térmica. Cada dupla conseguia, assim, escrever um pequeno texto sobre a localização, temperaturas e chuvas em cada uma das cidades que eu havia escolhido e elas representavam os cinco tipos climáticos presentes em qualquer livro didático, à época. Trabalharam três períodos nesta tarefa. Ao término, abriram um livro didático. No Aplicação, pedi que trouxessem ou pegassem na Biblioteca. Em Gramado, tinham um livro por aluno, na época o Terra Brasileira, de Aroldo de Azevedo. Leram o texto do livro e ficaram empolgados ao comparar o que escreveram com o que o autor dava como características de temperatura e chuva de cada ambiente das cidades cujos gráficos analisaram. A alegria de descobrir que eles eram capazes de "escrever um livro didático" foi impressionante. Em Gramado, mais ainda, porque eles não se viam, inicialmente, como capazes de ler o gráfico. Então, uma estratégia usual, com leitura de mapa, leitura do gráfico, uma pequena redação, um exercício absolutamente simples, foi extremamente motivadora.

Outra coisa que eu gostava de proporcionar, sempre que possível, era trabalho de campo, sair com os alunos ou solicitar que observassem os espaços pelos quais circulavam. Fiz várias destas atividades, em várias escolas, em Porto Alegre e no interior, no período de 1965, quando comecei a lecionar, até 1972, quando retornei a Porto Alegre. Mas quando eu retornei ao Colégio Estadual Júlio de Castilhos (Julinho), em 1972, onde eu entrei por concurso, em 1969, já com a licenciatura concluída, um fato abalava a escola. Convém lembrar que, à época, até 1970, não se podia entrar no Julinho sem concurso. Portanto, eu fiz um dos últimos concursos públicos ali realizados. Como já disse, entrei na FACED UFRGS, como professora, em 1966, sem concurso, entrei no Aplicação também sem concurso. Mas no Julio de Castilhos era obrigatório o concurso para ingresso no magistério. Isto porque o colégio era classificado pela então Secretaria de Educação, há anos, como "escola padrão”. Era uma das quatro escolas que elaborava um currículo para o Ginásio e o Curso Colegial. Este currículo servia de modelo para as demais escolas, públicas e privadas. É comum ex-alunos dizerem “estudei em um colégio padrão”, mas o termo padrão não tinha relação com padrão qualidade, mas por ser padrão, modelo. Mas voltando ao tema saída de campo, logo que retornei ao Colégio, depois de dois anos no interior, houve um episódio triste com um professor de geografia, que era muito bem quisto pelos alunos. Ele saiu com alunos para um dia de trabalho de campo nas proximidades. Estava muito quente e alguns alunos resolveram nadar em um dos rios do roteiro de trabalho. Dois alunos se afogaram, o que fez com que eu e outros colegas realmente recuassem da decisão de promover saídas do campo. Saídas de campo passaram a ser realizadas, com alunos de ginásio e colegial, apenas dentro da cidade ou para entrevistas com políticos ou técnicos e pesquisadores, mais como conhecimento de outras posições e fazeres do que observação do espaço. Em Gramado, nesta linha de trabalho, participei de uma atividade bem interessante, que foi produzir, coletivamente, com outros professores, o primeiro guia turístico da cidade. Era o início dos anos 70 e o movimento de turismo estava aumentando. Foi uma ação do ginásio local junto com a Prefeitura, que envolveu conhecimento do espaço local e muitos trabalhos pequenos em campo. Outro movimento que aquela escola fez, envolvendo professores e alunos, e do qual participei, como professora de Geografia, foi estender a linha de plantio de hortênsias na direção do Município de Três Coroas. Até então e 
desde a década de quarenta, quando foi colocado o asfalto no trecho que segue até Canela, primeiro asfalto do Rio Grande do Sul, havia o plantio de hortências junto ao asfalto. Novamente a Prefeitura pediu apoio do Colégio para um mutirão de plantio. Para justificar pedagogicamente o mutirão, cada professor o relacionava com os conteúdos que trabalhava. Fácil para a Geografia. Então quando alguém passar por ali e olhar todas aquelas hortências que estão no acesso a Gramado, via Três Coroas, deve lembrar que foram os alunos do então Ginásio São Pedro (hoje Santos Dumont) que plantaram.

Mas temos que voltar aos desafios. Primeiro, para a maioria das atividades o desafio, como sempre, é a gente não ficar na mesmice, procurar articular algumas coisas boas com os alunos, fazer que eles se vejam como autores dos seus textos, coisas que foram comuns no início do trabalho como professora. Eu trabalhei muito pouco tempo como professora do antigo curso ginasial. Basicamente minha experiência mais longa foi com o que hoje é o Ensino Médio. No Julinho, o Ginásio foi extinto em 1974. Considerava a leitura de jornal fundamental. No entanto, o número de famílias que tinha assinatura de um jornal diário, na maioria nas turmas que lecionava, foi diminuindo muito, já nos anos oitenta, um indicador do empobrecimento da população. Hoje, com a possibilidade de TV e internet, o jornal impresso aparece em poucas residências. À época, dispondo do jornal, os alunos eram chamados a escolher um tema. Ele escolhia e, ao longo de um tempo, em geral um semestre, trabalhava naquele tema, agregando informações e levantando inconsistências. Depois, se fazia um seminário ou outro tipo de apresentação. Para completar, e dependendo do interesse da turma no tema, havia sempre uma atividade extra, como convite a palestrantes, que poderiam ser pessoas da comunidade, para conversar com os alunos. Isto permitia a eles outra visão, outra perspectiva. São muitas as informações que podem ser levantadas na própria comunidade: traçado de rua, levantamento do que existe em uma rua, a própria casa, que é uma referência. Considerava importante sair daquela coisa linear do texto comum a todos. Se eu retomar toda minha vida como professora, em poucos momentos eu tive cansaço por estar com alunos. Lógico que houve o cansaço físico por estar em sala de aula, já que lecionar, especialmente para adolescentes, é bastante exigente, fisicamente. Mas aquele desgaste emocional, porque alunos brigam ou perturbam, foram poucos momentos. Eu ainda gosto de estar em sala de aula, o que faço eventualmente.

Entrevistador: Quais foram as atividades de ensino de Geografia realizadas/ organizadas pela senhora que mais lhe marcaram?

Neiva Otero Schäffer: Vejamos, nós temos que diferenciar essa minha vida como professora em dois contextos: o primeiro, como professora em escolas onde atuava com crianças e jovens, o que corresponde, hoje, à Educação Básica (Ensino Fundamental e Médio) e que foi concomitante à UFRGS; e a outra é a vida como professora na universidade. Na educação básica, o desafio é a atividade prática. Ela está vinculada a um fato que não ocorre na universidade, que é o grande número de turmas que o professor tem que atender, com o mesmo adiantamento. Por exemplo, no caso do Júlio de Castilhos, eu chegava a ter 14 turmas do primeiro ou do segundo ano. Não havia Geografia no terceiro ano. Com o tempo, conseguia ficar só com os segundos. É bom lembrar que atuar nos primeiros anos é dramático numa escola que não tinha o nível anterior ao nível médio e cujos alunos eram provenientes de mais de 100 escolas. Já no Colégio Israelita, onde atuei entre 1966 e 1969, eu tinha de três a quatro turmas em um mesmo adiantamento e vários adiantamentos de 
Ginásio e uma turma de Magistério. Significa organizar uma proposta que eu pudesse gerenciar e que desse resultados. Nesse caso, acho que as práticas mais acolhidas pelos alunos, salvo aquelas em que é ver um filme ou qualquer coisa assim, diziam respeito ao uso de mapas, à possibilidade de trazer experiências deles para a sala de aula, por meio de discussões, relato de experiências. Algo que eles temiam e, paradoxalmente, gostavam era de fazer exposição oral, de prepararem alguma coisa nova para os colegas. Eu aproveitava esses momentos não só para fazer a correção de conteúdos, o que se mostrava secundário, mas como exercício do ser falante, do apresentar alguma coisa preparada, do olhar quem assistia. Lembro de explicar que cada um podia levar sua folha, podia olhar a folha, mas a mesma não podia ficar sobre a mesa. Se precisassem consultar deveriam levantar a folha, para evitar que houvesse interferência na emissão da voz. No Júlio e no Israelita, trabalhei muitas questões ambientais, era a saída que se tinha, durante a ditadura, de trabalhar o viés político. Nos anos setenta e oitenta, principalmente em uma escola como o Júlio, a gente sabia da observação que era feito sobre os professores, dos que entregavam nomes por qualquer desconfiança. Tínhamos um colega, inclusive, que se sabia que estava a serviço do DOPS. Ele, mais de uma vez me falou "por que tu tratas tanto esta questão (ambiental)?". Eu acho que ele gostava bastante do meu trabalho e queria me proteger. Era uma pessoa muito afetuosa e, de certo modo, ao me questionar, buscava me orientar: "Não fala tanto dessas questões ambientais. Isso não está bem no teu plano.” Ele era um professor, como eu, não atuava em setor do colégio, portanto, só poderia saber o que eu fazia em sala de aula, questionando os alunos. Eu respondia: "Está, professor, tá no meu plano." Não raro, ele argumentava: "Mas esses dados, os alunos estão discutindo e levando para o Grêmio." A minha saída era o IBGE: "Professor, eu só trabalho com dados do IBGE. São oficiais. Eu vou lhe mostrar que tudo isso aqui é do IBGE." Esse movimento de trabalhar bastante com questões ambientais levou a um trabalho interessante, que foi reunir para um projeto, a partir de solicitação de alunos, um grupo de professores: história, biologia, química, geografia, artes, educação física. Este grupo articulava atividades de caráter ambiental, de forma paralela ao currículo. Então, a questão da leitura dos jornais, a questão da discussão dos textos dos alunos com dados do IBGE, inclusive desmatamento, o papel das ONGS, que agora estão em voga, a gente já trabalhava e encaminhava denúncias. Na avaliação, contava o comprometimento com as atividades extracurriculares: fazer as tarefas de leituras extras, leituras de espaço, e trazer para a discussão em aula. Eles sabiam que isso "não valia nota", mas valia o fato de ser feito ou não feito ao longo do mês ou do bimestre; outra proposta era assistir palestras, sobre qualquer tópico. Eles andavam sempre descobrindo uma palestra para ir assistir em grupo, porque aí, já que iam "em bando”, já faziam amizade. À época, era mais fácil resolver a questão da passagem de ônibus para tais atividades. Hoje o custo do transporte está muito pesado para o aluno. Lembro o sucesso que foi quando o José Lutzenberger retornou. Muitos foram ouvi-lo. Descobriram o Lutzenberger, que eles já estavam lendo. Como proposta de sala de aula, as palestras de pessoas de fora da escola, sempre foram importantes. Eles ouviam, faziam uma resenha da palestra e apresentavam em sala de aula ou preparavam uma atividade expositiva, visual, em grupo, para apresentar.

Sobre atividades em grupo, considero que são muito boas, quando a tarefa exigida pelo professor permite que todos participem. Caso contrário, é divisão de tarefas e perda de tempo em aula. Eu sempre pensei o trabalho em grupo como alguma pergunta cuja resposta exigiria a busca de materiais e que exigia, mais do que tudo, que todos se envolvessem. Trabalho em grupo é trabalho de sala de aula, nunca é 
trabalho para ser feito em casa, e o trabalho em grupo, como qualquer trabalho, exige que o professor fique quieto em sala de aula e circule. Professor bom, para mim, é professor caminhante, e para ser caminhante, ele não pode ser falante. Óbvio em que há momentos em que o professor tem que fazer uma apresentação, tem que fazer uma exposição inicial ou de conclusão, tem, inclusive, que fazer com que eles tenham postura de escuta, postura de registro. Eu fico muito assustada quando me chamam para fazer uma palestra, para falar a uma turma de alunos e os alunos sentam quietos sem um papel na mão, sem um caderno, sem um lápis, sei lá, como se fossem à missa! Não são preparados para a atividade. Às vezes, o professor não disse mesmo quem vai falar ao grupo, sobre o que vai falar e o que eles devem perguntar. Naturalmente que o aluno não tem perguntas a fazer sobre um assunto que ele desconhece. Só sabe perguntar quem já tem certo conhecimento do assunto. Se o aluno vai a uma palestra sem conhecer nada, ele não perguntará, e aí o palestrante sente o "desespero" do professor da turma: "Alguém tem pergunta?" Lógico que ninguém terá perguntas a fazer, não poderá ter pergunta.

Outra coisa que eu gostava muito de fazer com as minhas turmas, e fiz várias vezes, era propor que escrevessem cartas. Era uma atividade sempre em parceria com o professor de língua portuguesa, que usava a carta como uma avaliação de redação. No mínimo, uma carta era escrita por ano. Foram muitas cartas escritas para políticos, para secretários de estado e para o próprio presidente da República. Todas as turmas faziam suas cartas com pedidos ou sugestões, que podiam ser em defesa da Amazônia, contra o uso de agrotóxicos, em defesa das baleias, etc. No início dos anos 80 , foram muitas cartas ao governador do estado sobre a questão dos agrotóxicos, sobre o aumento da quantidade de agrotóxicos em uso e a contaminação do solo. As cartas estavam sempre ligadas a uma unidade do plano de estudos. As respostas chegavam. Raras vezes, individuais, para o endereço do aluno, o que era um acontecimento. Normalmente uma resposta bem protocolar, encaminhada ao colégio. Mas respondiam. Escrever cartas para colegas de escolas de outros municípios era outra variante da mesma estratégia. Mas é preciso ter um professor companheiro, para enviar uma cartinha bem escrita.

Outra atividade que realizei, até encerrar minha atuação no Curso Colegial, foi visitar a Assembleia Legislativa e encontrar algum deputado para discutir um assunto que estivesse em pauta. Eles aprendiam a fazer o contato, marcar horário, anunciar o assunto. Era muito bom, porque os deputados os recebiam bem e respondiam às perguntas que levavam. Mais de uma vez convidaram alunos para almoçar. Não rara conquistávamos alunos. Era interessante ver. Eles iam tão satisfeitos com uma crítica, um comentário e voltavam com ideias opostas. Em aula, após a apresentação, havia a reflexão.

Foram muitas coisas, muitos momentos, e nesses momentos eu não estou colocando fora a criança com a água do banho. Há momentos de leitura do livro, há momentos em que o questionário é necessário, há momentos em que a fala do professor é indispensável, há momentos em que a anotação no quadro é indispensável. Agora, sempre isso estará no meio de um plano de trabalho bem pensado. Quem não planeja, dá uma brilhante aula expositiva, o professor tem cacife para isso. Hoje esta falta de planejamento me assusta. Vejo que, quando muitos professores começam a faltar e um professor é chamado a juntar turmas, o que ele planeja é desconsiderado. O professor ganhando muito mal, faltando por desespero, às vezes, por cansaço, por encomodação, por desânimo, é uma imensa sonegação da carga horária que os alunos mereciam receber.

Sobre o trabalho na universidade, ser professora é outra coisa. Eu não fui uma professora criativa, mas dedicada. Tive colegas maravilhosos, criativos, inovadores. 
Acho que, na graduação, uma prática que talvez tenha marcado os alunos, e sobre isto comentam quando os reencontro, foi a obrigatoriedade com o compromisso mais fundamental e tradicional: ler os textos que tinham que ser lidos. Trabalhei muitos semestres com as disciplinas do início do curso, aquelas introdutórias ao curso, as que tratavam da formação do conhecimento geográfico, com a epistemologia da geografia que, nas primeiras aulas, era a história da geografia mesmo. O meu comprometimento, o que eu sentia como compromisso de um professor na universidade, era mostrar a leitura, envolver o aluno com a leitura. Não há milagre. Pode-se fazer uma excelente exposição, repeti-la e atualizá-la, mas o aproveitamento será diferente para o aluno que lê. Ele escuta com prazer, mesmo discordando e vai além. Houve uma prática que apliquei por muitos anos e era dirigida aos alunos de primeiro semestre. Eles entravam no curso de Geografia, e acredito que continue sendo assim hoje, com uma diferença muito grande de qualidade acadêmica, de preparo para estudos superiores, em função do que haviam estudado, ou não, no ensino médio. Entre o primeiro lugar e o último a distância era muito grande. Os alunos que ingressavam nos primeiros lugares apresentavam um desempenho no vestibular que teria permitido o ingresso em cursos mais procurados. Já os últimos lugares eram os últimos no desempenho no vestibular. Como é que se trabalha com uma classe assim? Alguns apresentavam uma dificuldade imensa de construir um parágrafo e outros uma facilidade enorme, porque estavam habituados a ler e a redigir. O que fazia? Encaminhava uma leitura, exigia uma leitura semanal. Eram quinze semanas, no mínimo, já que o semestre acadêmico tinha entre quinze a dezessete semanas por semestre. Ao término do semestre, os alunos precisavam ter feito a leitura de doze artigos. Às vezes, o artigo não era um artigo, mas um livro de pequeno porte. Eles liam e redigiam uma resenha de não mais que uma página. A resenha exigia a capacidade de sintetizar a leitura, de dar um parecer sobre o que foi lido, o que é muito difícil se a leitura não foi entendida. Imagina o esforço para transformar um texto técnico de quatro a cinco páginas, em uma página. É um exercício muito pesado. Era comum que não fizessem a primeira e a segundo resenhas. Aí eu alertava que não fariam a prova final sem a entrega das doze resenhas. Não precisam entregar toda a semana, mas seria melhor. As duas primeiras, três primeiras não vinham, dali a pouco eles viam que não haveria alternativa e faziam as resenhas. Eu lia, mostrava a correção, os bilhetes, e retomava o trabalho, que era guardado em um envelope para cada aluno. Algumas vezes, pedia que refizesse a leitura e a síntese. Nas últimas resenhas, a diferença de redação era impressionante. Não reclamavam mais, o trabalho fluía. Para mim era gratificante. Dava muito trabalho discutir com as turmas, nas primeiras aulas, sobre a validade da tarefa, sobre a razão daquilo que viam como trabalho que não cabia na universidade. Mas observar, ao término, o envelope de cada um e o avanço no desempenho, me dava a segurança que a prática era positiva. No último dia do semestre, quando devolvia a cada um aquele pacote de resenhas, provavelmente para ser descartado, porque estavam feitas e avaliadas, pedia que comparassem as primeiras com as últimas. Não havia nota ou conceito em cada resenha, apenas era avaliado o comprometimento, se fizera ou não o trabalho. Era notável a diferença. Lembro do que ocorreu com um rapaz que, há poucos dias, me escreveu perguntando se eu ainda fazia orientação. Encerrada a entrega das resenhas do semestre, fui para a minha sala. Logo depois ele chegou. Encostou-se à porta e começou a chorar. Fiquei perturbada e perguntei se havia acontecido alguma coisa. Ele respondeu "as resenhas". Perguntei o que havia com as resenhas. Disse que estavam feitas, estavam boas. Ele pegou as resenhas e as amontoou por data, explicando. "Olha a minha primeira e olha a última." Expliquei que sabia, 
que era por isso que eu trabalhava assim todo o semestre, que com os demais colegas também acontecia aquilo. Ele era filho de uma funcionária de limpeza de uma escola, sem pai, morador da Restinga, com preparo mínimo para o ingresso no curso. Ele chorava por ver quanto melhorara na capacidade de ler e escrever. Brinquei com ele dizendo que ganhara um prêmio com o choro dele. Nem sempre sentiam tão intensamente, mas foram muitos os que melhoraram para seguir o curso. Este meu compromisso com ler e escrever gerou outra situação engraçada. Havia um aluno que discutia muito comigo, porque eu era muito "reclamona" em relação aos trabalhos, que minhas aulas eram muito "certinhas". Ele era um aluno muito criativo e naquele período, início dos anos oitenta, no departamento ainda tinha essa exigência de prova escrita a cada dois meses. Eu não gostava daquilo, preferia avaliar conforme minha experiência no Aplicação. Preparei para a turma uma prova com questões que exigiam respostas curtas e uma dissertação. Corrigia o que escreviam com caneta vermelha e ia corrigindo e completando com perguntas sobre porque não desenvolvera ou porque não incluíra algo mais. Ao devolver as provas, ele não estava presente. A dissertação dele estava excelente. Ora, quanto melhor um trabalho, mais eu riscava. Porque me daria ao trabalho com aluno que não demonstrara empenho em responder? Na entrega, expliquei como agia na avaliação da prova e o ambiente estava tranquilo. Ele recebeu a prova por um colega. Logo em seguida, tivemos um trabalho de campo em Estrela. Visitamos a eclusa. Notei que estava irritado e não falava comigo. Perguntei o que estava acontecendo e ele reagiu, áspero, pedindo que eu não chegasse perto dele. Quis saber o que houve e outro aluno, bastante gentil, explicou que a causa era a prova. Ele reagiu, mais irritado, sobre a "porcaria" da prova, que havia jogado no lixo, que nem olhara, porque estava toda riscada de vermelho. Achei graça e expliquei que estava toda riscada porque fora a melhor prova da turma. Me olhou e questionou: “Como a melhor prova? Toda riscada!". Expliquei que não ficaria me preocupando em riscar prova de quem não me diz nada. Que a dele fora bem riscada, porque estava muito boa e tudo que eu riscara era para que ficasse ainda melhor. O impasse foi resolvido, tranquilamente. Mas aprendi que, em alguns procedimentos, precisamos ter cuidado. O vermelho é bom, mas não para bilhetes, complementações ou elogios. No mínimo, não se pode entregar uma prova como aquela por meio de um colega.

Entrevistador: Como a senhora percebe as diferenças no ensino de Geografia do seu tempo de trabalho para os dias atuais?

Neiva Otero Schäffer: Eu acho que temos dois pontos diferenciadores. À época em que eu comecei a lecionar geografia, havia poucos recursos para o aluno e mesmo para o professor. Com isto, o desempenho do professor pouco podia ser comparado. $\mathrm{O}$ que dizia era o certo. A maioria dos alunos não tinha onde buscar informações complementares sobre o que professor apresentava. Eles pouco traziam para a aula além da leitura do jornal — da imposição que eu fazia da leitura do jornal — porque, para os jovens ou mesmo para os estudantes universitários, naquele período do final dos anos 60 aos 80, eram mais escassos os recursos. Eles dependiam quase exclusivamente dos livros e, mesmo assim, eram poucos os títulos disponíveis. No caso da Geografia acadêmica, a multiplicação de obras é do início dos anos 80, com muitos livros sendo traduzidos e com o retorno de pesquisadores que haviam saído do país, como, por exemplo, Milton Santos, caso modelar. Há um boom de novas produções. O professor vivia preso às geografias tradicionais e, depois, à geografia do subdesenvol- 
vimento, vista com certa empolgação ou desconfiança. Esse período no qual comecei a lecionar, 1965, 66 aos anos 80, o professor é dono da sua sala de aula. Há uma sala muito mais "tranquila”, porque há uma forma de controle da família, da sociedade e da escola sobre esse aluno. As escolas dispunham de pessoal de apoio, havia pessoal de apoio: um funcionário no corredor, um funcionário no pátio, um funcionário no recreio. Os alunos eram muito mais tolhidos. Ao observar o ensino de geografia hoje, e continuo rotineiramente dentro de um colégio, mesmo sem assumir a regência de classe, penso que uma grande diferença é o despreparo dos nossos professores. É triste e, aparentemente preconceituoso, afirmar isto. Os professores não vêm mais de classe média ou média alta. Eles chegam com uma defasagem de experiências e oportunidades que não é culpa deles, é do que esse país se tornou em desprestígio ao trabalho do professor. Ou seja, têm mais dificuldades para planejar, para decidir, para reconhecer recursos para o ensino, alguns já banalizados nas mãos dos alunos. Outro problema que o professor enfrenta e que, em muitos momentos, é um severo desafio, é a atitude dos alunos. Eles não são mais alunos que vêm de famílias que seguiam um modelo de proteção e controle dos filhos. Boa parte dos alunos estava em sala de aula e ali permanecia por decisão e acompanhamento de famílias que valorizavam o estudo. A universalização do ensino, a partir do final dos anos 80 , a ampliação de vagas não foi compatível com o necessário reforço de pessoal de apoio e de formação docente para atender esta nova massa de alunos. O professor tem nas escolas jovens que não são alunos e precisam se tornar alunos, repetindo a reflexão apresentada em trabalho publicado por Maria Luiza Xavier (2014). No passado, havia alunos em sala de aula, porque a família e a escola já haviam transformados jovens em alunos, trabalhando com valores: respeito ao professor, respeito à escola, o estudo é importante, quem não estuda não tem emprego, etc. Esse discurso não aparece mais. Em casa, a família tem pouco tempo para o encontro. Não raro, os jovens estão aos cuidados de avós. $\mathrm{O}$ acompanhamento, o apoio aos estudos, em casa, é precário. Nas escolas públicas, não poucos jovens no ensino médio não dispõem, de forma regular, de recursos para cobrir os gastos com passagens e sua frequência é irregular. Então, acredito que é muito mais difícil ser professor hoje do que foi há uma ou duas gerações. O que um professor tem à disposição, no colégio, é um livro didático, que não sei como ficará para o próximo ano, com a política de restrição do atual governo. Por outro lado, o professor é muito mais exigido pelo questionamento do aluno, que viu ou ouviu em algum lugar sobre o tema em pauta. É comum o professor se queixar do celular que o aluno tem em mãos. Ou serve à distração ou serve a buscar o confronto de conhecimento, o que poderia ser salutar, se orientado, mas que não é quando o foco é confrontar. Acho que o professor tem que ter uma paixão muito grande pela docência, para se ver escutando o aluno e gerenciando esse conhecimento, para possibilitar uma formatação acadêmica ao conhecimento geográfico. Não é tarefa fácil. Considero que está difícil ser professor na Educação Básica, nesse momento, e, se eu situo este momento como anterior mesmo ao atual governo, é porque vejo como resultado de um movimento que veio ao longo desses últimos anos e num quadro que é mundial e que nos afeta muito mais. Mas ter no neste governo alguém que não é preparado, que ao se expressar remete a uma formação medíocre, que não respeita ciência, que não respeita pesquisa, que parece não saber do que fala, é um drama imenso! E não sei o quanto de força existe na intelectualidade, hoje, para fazer frente ao que está vindo e ao que virá. Ter um presidente que admira um indivíduo que fala em terraplanismo, OVNIs e outras coisas deste tipo... é de nos deixar sem resposta sobre o ensino. 
Entrevistador: Que recomendações a senhora daria aos jovens professores de Geografia?

Neiva Otero Schäffer: Abnegação (isso não é uma razão para abandonar a profissão), comprometimento com a profissão, solidariedade com os demais professores, não se isolar, compartilhar, andar em grupo, andar em múltiplos grupos e aprender sempre. Não pode parar de ler, de estudar. E se pensa que a situação irá melhorar de imediato, não irá. Melhorará com o comprometimento de todos. Portanto, não dá para se abandonar, a si e à profissão. A geografia é extremamente importante no currículo, para ser uma disciplina de memorização e de professor palestrante. Ao primeiro aluno que olhar e ver nele uma carinha meio atravessada, converse, converse antes que o perca. Eu acho que a educação, principalmente a pública, deve ter, como o título do filme chinês, a ideia de "nenhum a menos". Acho que essa preocupação de não ter nenhum aluno a menos e de ver o que está acontecendo na sala de aula de geografia para ficar sempre resgatando o aluno, passa pela orientação do professor Nestor Kaercher, apresentada em várias de suas palestras, de que na sala de aula não pode ter aluno "orelha" e professor "boca". Ser professor é questão de comprometimento. Ao optar por uma licenciatura, qualquer licenciatura, como a Geografia, é preciso um comprometimento, abnegação com aquilo que você se compromete e com a permanente formação. Não dá mais para ser um indivíduo que obteve o diploma e que acredita que está pronto para trabalhar sem novo retorno aos estudos. Em nenhuma profissão isto é hoje possível, porque a renovação de conhecimentos e de equipamentos é muito rápida e é preciso acompanhar este ritmo das inovações.

\section{Referências}

CASTRO, Magali de. Percorrendo os caminhos da profissão docente: estudo a partir da trajetória de professoras formadas nas primeiras décadas do século XX. Belo Horizonte: PUC/Minas, 2005. Relatório de Pesquisa.

FONTANA, Roseli Cação. Como nos tornamos professoras. Belo Horizonte: Autêntica, 2000.

FREITAS, Maria Teresa de Assunção (org.). Memórias de professoras: história e histórias. Juiz de Fora: UFJF, 2000.

VIDIGAL, Luis. Os testemunhos orais na escola: história oral e projectos pedagógicos. Porto, Portugal: Edições Asa, 1996.

XAVIER, Maria Luiza Merino. A construção da categoria social aluno: aprendizagens, socialização e disciplinamento em questão. Currículo sem Fronteiras, Brasil, v. 14, n. 2, p. 97-108, 2014.

\section{Publicações da entrevistada (seleção)}

CASTROGIOVANNI, Antonio Carlos; CALLAI, Helena; SCHÄFFER, Neiva Otero; KAERCHER, Nestor (org.). Geografia em sala de aula: práticas e refexões. 5. ed. Porto Alegre: AGB, 2010. v. 1.

FILIPOUSKI, Ana Mariza; MARCHI, Diana; SCHÄFFER, Neiva Otero (org.). Teorias e fazeres na escola em mudança. 1. ed. Porto Alegre: Editora da UFRGS, 2005.

FILIPOUSKI, Ana Mariza; SEFFNER, Fernando; LOSS, Isabel Emilia; SCHÄFFER, Neiva Otero (org.). Trânsito e Educação: itinerários pedagógicos. 1. ed. Porto Alegre: Editora da UFRGS, 2002. v. 1.

NEVES, Iara Conceição; SOUZA, Jusamara; GUEDES, Paulo; SCHÄFFER, Neiva Otero; KLUSENER, Renita (org.). Ler e escrever: compromisso de todas as áreas. 9. ed. Porto Alegre: Editora da UFRGS, 2011. v. 1. 
ROSSI, Aida Maria; TRAVERSINI, Clarice; SCHÄFFER, Neiva Otero; PEREIRA, Nilton (org). Ensino Médio: docência, identidade e autoria. 1. ed. São Leopoldo: Oikos, 2010.

SCHÄFFER, Neiva Otero. A cidade nas aulas de Geografia. In: CASTROGIOVANNI, Antonio Carlos; CALLAI, Helena; SCHÄFFER, Neiva Otero; KAERCHER, Nestor (org.). Geografia em sala de aula: práticas e refexões. 5. ed. Porto Alegre: AGB, 2010. v. 1, p. 105-112.

SCHÄFFER, Neiva Otero. Ler a paisagem, o mapa, o livro... In: NEVES, Iara Conceição; SOUZA, Jusamara; GUEDES, Paulo; SCHÄFFER, Neiva Otero; KLUSENER, Renita (org.). Ler e escrever: compromisso de todas as áreas. 9. ed. Porto Alegre: Editora da UFRGS, 2011. v. 1, p. 86-106.

SCHÄFFER, Neiva Otero; COSTELLA, Roselane. A Geografia em projetos curriculares: ler o lugar e compreender o mundo. 1. ed. Erechim: Edelbra, 2012. v. 1.

SCHÄFFER, Neiva Otero; DAMIANI, Anelisa; BLAUTH, Nely; STROHAECKER, Tânia; DUTRA, Viviane (org.). Ensinar e aprender Geografia. Porto Alegre: AGB, 1998.

SCHÄFFER, Neiva Otero; KAERCHER, Nestor; GOULART, Lígia Beatriz; CASTROGIOVANNI, Antonio Carlos. Um globo em suas mãos. 3. ed. Porto Alegre: Penso, 2011. v. 1.

SCHÄFFER, Neiva Otero; KAERCHER, Nestor; REICKWALD, Guilherme. A Geografia no ensino médio. In: CASTROGIOVANNI, Antonio Carlos; CALLAI, Helena; SCHÄFFER, Neiva Otero; KAERCHER, Nestor (org.). Geografia em sala de aula: práticas e refexões. 5. ed. Porto Alegre: AGB, 2010. v. 1, p. 159-162.

SCHÄFFER, Neiva Otero; TRAVERSINI, Clarice; TOUGUINHA, Lizete (org.). A construção cotidiana da docência no Ensino Médio 1. ed. São Leopoldo: Oikos, 2013. 